OPEN ACCESS

UNIVERSITY OF THE

WEST of SCOTLAND

UWS Academic Portal

\title{
Enterprise and entrepreneurship on islands and remote rural environments
}

Burnett, Kathryn; Danson, Mike

Published in:

International Journal of Entrepreneurship and Innovation

DOI:

$10.1177 / 1465750316686237$

Published: 01/02/2017

Document Version

Peer reviewed version

Link to publication on the UWS Academic Portal

Citation for published version (APA):

Burnett, K., \& Danson, M. (2017). Enterprise and entrepreneurship on islands and remote rural environments. International Journal of Entrepreneurship and Innovation, 18(1), 25-35.

https://doi.org/10.1177/1465750316686237

\section{General rights}

Copyright and moral rights for the publications made accessible in the UWS Academic Portal are retained by the authors and/or other copyright owners and it is a condition of accessing publications that users recognise and abide by the legal requirements associated with these rights.

Take down policy

If you believe that this document breaches copyright please contact pure@uws.ac.uk providing details, and we will remove access to the work immediately and investigate your claim. 
Enterprise and Entrepreneurship on Islands and Remote Rural Environments

Lead Author: Kathryn A. Burnett, MA (Hons), MSc, PhD, PG Cert, Senior Lecturer; CoDirector, Scottish Centre for Island Studies; Contact Details: School of Media, Culture and Society, University of the West of Scotland, Ayr Campus, University Avenue, Ayr KA8 0SX; Phone: +44 (0)1292 886482; Email: kathryn.burnett@uws.ac.uk

Co-Author: Mike Danson, DLitt, AcSS, FIED, FeRSA, Professor of Enterprise Policy; CoDirector, Scottish Centre for Island Studies Heriot-Watt University; Contact Details: School of Management \& Languages; Dept. of Business Management, Heriot-Watt University, Edinburgh, EH14 4AS Phone: +44 (0)131 4513840 Email: m.danson@hw.ac.uk 


\title{
Enterprise and Entrepreneurship on Islands and Remote Rural Environments
}

\begin{abstract}
Although there has been increasing interest in rural enterprises, relatively little has been written on enterprise and entrepreneurship on islands where problems tend to be different, additional and exaggerated. Economic and cultural development agencies intervene to support such remote and isolated communities but the significance of the dominant metropolitan paradigm in the peripheralisation of those establishing and running businesses on islands needs critiqued. This paper contrasts experiences but highlights similarities, rather than differences, of rural SMEs in developing countries and comparative northern European locations. The key role of social capital, cultural values and norms is analysed and comment presented on small island experiences. Arguments are made for policies to be proofed for locational differences and for further research to understand the opportunities offered by islands and coastal communities in a world where the particularities of place and space are increasingly valued, and aspects of remoteness can be re-articulated to good effect.
\end{abstract}

Keywords: remote, rural, island, enterprise, Scotland, development 


\section{Introduction}

A key element of the restructuring of rural and small island economies both in the developing and developed world has been the promotion of enterprise and entrepreneurship that most especially privileges local culture as a key development resource, and indeed natural local environments as culturally realised via 'localism', sustainability and ethical consumerism (c.f. Throsby, 2015; Tisdell, 2006; OECD, 2005). This trend is global but subject to uneven conditions of opportunity and realisation with increasing emphasis given to the transformative potential of cultural economies globally (UNCTAD, 2013). Consequently, comparative analysis and critique is useful to share. Scotland has under the Scottish government championed the importance of the sustainable development goals ${ }^{\mathrm{i}}$ not least as a shared and globally responsible vision for developing and developed countries alike (Scottish Executive,2005; Scottish Government, 2016). Pato and Teixeira (2016) demonstrate that rural entrepreneurship research can be typified by eight areas of focus ranging from the entrepreneurs' demographic and psychological traits; organisational characteristics; embeddedness; rurality; growth and development; to policy measures, institutional frameworks, and governance. We have argued (Danson and Burnett, 2014) that businesses in rural island and remote areas have all the issues facing SMEs and new start-ups anywhere, but importantly they tend to face different, additional and exaggerated problems. Furthermore, remote rural Scotland must contend with rural poverty concerns, multiple deprivation, land and asset iniquity and social exclusion challenges (Shucksmith et al., 1996; Bryden and Geisler, 2007; Skerratt et al. 2014) offering some shared insight for remote rural and small island experience elsewhere. Despite considerable shifts to counter and ameliorate these development concerns Scotland's small islands and remote rural areas require ongoing critique of what is 'making a difference' not least 'proofing' for this locational difference and moreover we note that it is the very specificity of context that requires perhaps most 
focused attention (c.f. Shorthall and Alston, 2016 on the complexities of applying national rural proofing agenda to contexts elsewhere, for example). There are very few studies on how these firms and their entrepreneurs and agencies cope with the harsher business environment, however, and this applies as strongly to the recent work on transition and emergent economies (Smallbone and Welter, 2006 ; Smallbone et al., 2014). Similarly, in the expanding literature on island studies there is opportunity for further focus on rural island enterprises and entrepreneurs, including the nature of representing rural and remote places as entrepreneurial (see Burnett \& Danson, 2004, 20014; Baldacchino and Fairbairn, 2006; Baldacchino, 2010).

Therefore, this paper considers the research, policy and practice literature on island enterprises and entrepreneurs, and reflects on the role and activities of agencies and strategies at different levels as they are especially relevant in such remote and often isolated communities in the western world, and of increasing importance in the developing world as discussed later. The significance of the dominant paradigm of agglomeration, clusters, connectivity, proximity and competitiveness is explored and especially its role in the peripheralisation of those establishing and running businesses on islands. Contrasts are offered between experiences from comparative northern European locations of smart specialisation, innovation and resilience, and attention drawn to the roles of social capital, relationships and cultural values and norms, and these are applied to inform analysis of developing country contexts. Analysis of how forces and obstacles apply in island and remote rural environments is consistent with the arguments of Baldacchino (2006), Kelman (2007) and Danson and de Souza (2012) that, even in the modern world of ITC and internet connections, there are inherent disadvantages in these distant locations but that the characteristics of remoteness and otherness provide some countervailing benefits to entrepreneurs. 
At such an interesting and pivotal time in Scotland's history, the focus of this paper on the islands and remote rural parts of Scotland is especially significant. ${ }^{\text {ii }}$ The 'placeness' of cultural resources is understood as a useful for development and diversification. Parallels are apparent in a number of developing (e.g. Vietnam), internal colony (e.g. Arctic) and transition economies (e.g. Croatia, Abu Dhabi), (see Smallbone and Welter 2006; Smallbone et al., 2014) to learn from and to share experiences on applying and promoting the cultural values of coastal and island communities in their respective countries' socio-economic development. Examples for focus would most especially be in tourism-related business but also in the broader cultural industries' expectations of places that are both 'good' to live and work in (c.f. Harling Stalker and Burnett, 2016). What is termed as 'good' island enterprise, and how ideas of 'island culture', island sustainability agenda, or the articulating of relationships of trust and stewardship within small community living are mapped to development policy and enterprise practice, is invited for review here. Our research recognises Scotland's island enterprise policy shift towards increased synergies and coproduction of policy, pluralistic responses to growth challenges and an informed historical perspective of current socio-economic opportunities. Our Scottish island focus where the fragility of economic, cultural and social sustainability is well noted ${ }^{\text {iii }}$ is offered as a contextual reference point for small island community experience elsewhere, informed not least by island studies and regional studies research but also by particular experience on the accelerated pace of change informing island culture and environments globally (Throsby, 2015) and the value of critiquing entrepreneurship context more widely, not least in terms of place (Johannisson, 2009; Welter, 2010).

\section{Islands Communities as Space and Place: Research Policy and Practice}

Islands and other places defined by the sea, both as spaces and cultural places, are understood to offer 'otherness' and difference, especially in respect of tourism and culture (DeLoughrey, 
2007; Edmond and Smith, 2003; Baum, 1996), but also they offer environmental claims of 'pristine' and 'isolated' terrains (Hennessy and McCleary, 2011). However, such definitions are often contested or ambivalently accepted 'within' the community. This proposition that islands and communities influenced by the sea can be examined in their own terms has been increasingly advocated by 'island studies' perspectives (Baldacchino, 2006; McCall, 1994) and in the economic development field. So, arguably, islands are not simply bounded places of defined 'otherness' or coasts delineated by the sea but rather are complex, layered and highly contested spaces of cultural and socio-economic distinction (Edmond and Smith, 2003). Islands, developing or developed environments, are physically understood as places and communities set apart from other land mass and yet they are always bound into relationships with their relative neighbours of either other islands and/or of 'mainland'. Similarly, these entities rather than being set apart from modernity are very often indicators of the inexorable reach of modernity, and 'emblematic of both the opportunities and challenge of modern capitalism' (Nicolson, 2002). It has been shown that this is not always recognised in either the academic or the development literature (Burnett, 2011).

Whilst isolation is a key defining characteristic and undoubtedly the lived reality for much of island experience, environment and social functionality, islands are also very much spaces that link and map into relational activity and events around them. With the increasing emphasis on social capital and networking in enterprise studies (Atterton, 2007; Atterton et al, 2011), this becomes all the more apposite for island studies.

Distance, isolation and peripherality are therefore both social constructions (Danson and de Souza, 2012) - well established discourses and narratives told and retold in various forms - as well as measurable terms of mapped physical difference (see Lowe et al, 1998). This shifting nature of discourse and representation is important; there is no global consensus over the very concept of 'islandness', as case studies of islands and comparative experiences demonstrate. 
Some, such as Hay (2006), have warned against a tendency to privilege islands - and indeed island residents especially - as 'other'; and not to obscure the geographic realties of islands through reference to literary or fictional accounts. There has been a recent focus in island studies on fostering responsive research to the nature of island economics, environments and culture (see, for example, Island Studies Journal, or Shima, the International Journal of Research into Island Cultures). Although there have been volumes on collections on rural and remote enterprise before, (Curran and Storey, 1993; Henry and McElwee, 2014; North and Smallbone, 2006), only recently have 'island business and entrepreneurship' begun to be explored (Atterton et al, 2011; Baldacchino, 2005, 2012; Danson and Burnett, 2014; McIntosh and Renard, 2009).

Definitions of many islands and island groups, or archipelagos, have been contested as places of value and of neglect. For instance, in Scotland the Hebrides, Orkney and Shetland have each been unfavourably categorised as both economic and cultural backwaters throughout the C20th, although in contradiction all of these island regions have occupied key roles in global trade and industry in former times. In the last three decades, especially with the exploitation of North Sea oil (particularly in the case of Shetland), and with the re-invigoration of cultural heritage, coupled with a so-called alternative tourism focus on championing indigenous 'ways of life', histories and environment, it became clear that policy was shifting to reappraise the 'localness' and particularity of each island region's history and landscape. In economic development terms Scotland's island economies express themselves as a confident enterprise matrix of natural and cultural product, each mapped to the strengths of their island situation. Nonetheless, the complex (complicit) nature of this is well noted here as an example of Harvey's (2006) concerns of the attendant risks of capitalism, including struggles over space and meaning, and the cultural and aesthetic fetishization of goods and experiences, not least indigenous island cultural claims (Clifford, 2001). Claims to what is 'of 
a place' and a 'people' informs our critique of enterprise trends. We note Clifford's call for a fuller appreciation of the nature of articulated sites of indigeneity, including sovereignty, in various and competing terms, as a fluid yet useful debate informed by First Nation peoples' experiences. As in the developing country cases discussed below, island cultures and economies in Scotland are currently contending with a need to present a modern set of economic growth and enterprise responses scaled for sparsely populated, remote rural community living that champions (commodifies) ideas of cultural and physical distinctiveness (peripherality and cultural 'margins'). As others have noted elsewhere performing such indigeneity aspects is not without its tensions (e.g. DeLoughrey, 2007; Graham and Penny, 2014; Royle and Tsai, 2008) and in Scotland, too, tensions are noted around the commodification of what might be termed the authenticity of Hebridean Gaelic, Shetlandic and Orcadian island traditions, and all with a backdrop of historical tensions that saw each island region subjected to cultural attack and dismissal (Burnett, 2011; Heddle, 2010; Hunter, 2010). Enterprise policy has embraced the potential of island spaces and experiences with a new vigour and focus. Scotland's island products articulate added value of islandness. Products range across tourism, food and drink, craft, arts and heritage but also energy, clean technologies, biomass developments, media and digital tele-networking. Champions are used to actively promote the island and remote rural regions successes with active use of social media and digital narratives to circulate images and accounts of enterprise stories, products and people (Haskins/CTA, 2012). Complementing this increasing interest and research on the economies and cultures (natural and heritage) of islands has been an awareness of remote coastal communities (Altman, 2003; Carothers, 2010; HIE, 2011), albeit attracting less attention. Both geography and history matter in understanding such experiences, especially in a comparative context and, although our work focuses on the islands of Scotland, it is intended to inform and be informed by experiences from wider 
global perspectives. Examples from the literature on island co-operatives, the role of networking intermediaries (O' Gorman and Evers, 2011), small islands in Britain and Greece (Armstrong et al, 2006) and globally (Armstrong and Read, 2003; Baldacchino, 2010) suggest that there are common features and transferable messages on island enterprise in contrasting contexts, and to an extent these transcend the wider nation's development status.

Capitalism, and neo-liberal economies especially, generates uneven development (Harvey, 2006; Smith, 1990; Soja, 1985) and over the last few decades national and regional growth strategies and policies have prioritised competitiveness over a more equitable distribution of economic activity. This approach has led to further marginalisation and peripheralisation of communities and SMEs outside of the core, whether defined in terms of geography or economy (Danson and de Souza, 2012: 2). Across the world, developing and developed, urbanisation and globalisation have worked in parallel to progressively concentrate development in central regions and to privilege cities and city-regions by stressing the benefits of proximity and agglomeration economies (Danson and de Souza, 2012). Locations at some distance from the capital and centre of the national economy, challenged by distance and low population densities, face particular problems with the promotion of the core, and the specifics of islands and remote coastal territories exaggerate these to a greater degree.

This brief exploration of the form and direction of economic development strategies confirms the need to consider the local conditions and environment if the performance and behaviours of island and other remote enterprises and entrepreneurs are to be understood. The penetration of economic forces and flows to even the most isolated communities means that knowledge transfer and exchange across different development contexts is feasible and desirable. That said, it is also necessary to recognise that 'island and coastal studies' covers a wide range of types and sizes: from island states such as Malta, Australia or Iceland to those that examine peripheral island regions within larger territories including, for example, work 
on Japan's 'remote islands' or on the Faroes and the Ålands in Europe's northern periphery (Efimova and Kuznetsova, 2012). Rowe (2011), Royle and Tsai (2008) and Royle (2008) amongst others have analysed the common issues of socio-economic and cultural peripherality across the globe, and similar conditions and challenges can be identified in north western Europe, Canada's Atlantic islands (Harling Stalker and Phyne, 2014), northern Scandinavian and the Arctic region (Danson and Burnett, 2014).In this collection of essays examining rural entrepreneurship in an international context, there is prominence given in many of these island studies to that capacity for tourism and cultural enterprise, reaffirming the potential for the exchange of policy and practice across continents and highlighting the 'island' over the 'development' status.

\section{Policy contexts to solving the peripherality 'problem': a view from Scotland}

Reflecting the sectoral approach that typifies many national and regional economic interventions, such as clusters (Whittam and Danson, 2001) and those based on a triple helix (Etzkowitz and Ranga, 2009), there have been criticisms that these are less appropriate for remoter and island communities (see Rowe, 2011, referring to the OECD report on Scotland for instance). Such studies also highlight the need for well-integrated and coherent policies. The Scottish Government response was for "rural proofing within a more decentralised, mainstreaming framework [which] would help to overcome some of the weaknesses of the sectoral approach" (Rowe, 2011). Despite this official orientation and awareness of the issues and challenges facing peripheral areas, which is also seen at the levels of the European Union and individual countries (Danson and de Souza, 2012), Rowe (2011) still questions the extent to which rural is 'fully and centrally in the minds of policy-makers across all Directorates of the Scottish Government', and we might add departments of governments and other authorities in developing and transition contexts also (Pato and Teixeira, 2016; Smallbone and Welter, 2009). 
Since the 1970s, there has been an increasing appreciation across different and varied jurisdictions of the importance of governance arrangements and of institutional thickness and capacity especially; that is, of having the agencies and bodies with adequate expertise, influence and resources to support and advice in developing the economy at local, regional and national levels. While Scotland and Ireland have led in the evolution of model approaches (Danson et al, 2005), newer forms of organisation have tended towards dedicated semi-autonomous agencies with sufficient resources to intervene successfully within the territory (Bellini et al, 2012; Danson and Lloyd, 2012). Establishing the best institutional infrastructure of bodies to support economic development which is sustainable and appropriate has been taking place within an environment where partnership working and networking between actors and agencies are seen as essential (Cameron and Danson, 1999). For many places, growing and assembling the institutions and the personnel inevitably takes time and resources, both of which will be especially challenging for communities in remote and peripheral locations. With typically lower populations, higher costs and weaker professional labour markets (Hecla, 2008), island and remote rural communities across the world struggle to attract the attention, staff and funding to overcome the restrictions facing their enterprises, entrepreneurs and other participants in the local economy. Coupled with the core expectation that the dominant paradigm and policies are appropriate everywhere with their unthinking application in 'laggard' or 'backward' regions exacerbating their peripherality, the need for solutions and strategies which are fit for the purpose of remote and peripheral economies is paramount. To that end, there are instances of building successful institutional responses and frameworks suitable for island and remote rural coastal communities, however, and these often reject the imposition and importation of core solutions to problems and opportunities (see Danson and de Souza, 2012, for examples).

\section{Island proofing: development challenges and global trends}


Scotland offers a timely case study of politicised debates around economy, enterprise and culture. Recent attention on the issues of representation and participation in culture and polity around Scotland's 2014 independence referendum is emblematic of a longer running set of historical agenda whereby ideas of nation, region and indeed rurality have been re-examined and the nature of boundaries of difference, of belonging, of place and participation have been brought to the fore under banners of 'unification', 'equity' and 'influence', and not least in respect of the island regions (Scottish Office, 2015). The 2014 referendum raised consciousness in terms of ideas of Scottishness and the dialectic within political, cultural and economic spheres around what might be termed 'success' or indeed what is being meaningfully shared, and critiqued as 'speaking for Scotland'. Two particular aspects are of note here in illustrating similar drivers and forces acting on islands globally.

Firstly, the 'cultural turn' offers itself a platform upon which past and present economic policies might be assessed (Mulholland, 2008); consequently a heightened critique spurred on by the referendum debate has shone fresh and varied light upon what Scotland 'is', or indeed 'might be' as a socio-cultural terrain but also as an economic case study usefully shared amongst both current and future researchers and policy makers alike. Scotland remains, in contrast to much of the rest of the UK, a largely rural place. In the related yet distinct sphere of rural economy and governance considerable shifts have been made to publically comment on what the 'rural' offers Scotland and indeed what might 'Scotland' offer the rural - its people, places and practices. In 2005, it was noted for example that Scotland's rural areas are "a unique resource with significant long term potential as places to live and work. This special potential is replicated in only a few places in northern Europe and, arguably, nowhere else on this scale in the UK. Future lifestyle changes and technological development may well increase the demand for living and working in rural areas." (Scottish Government, 2005) The uniqueness of Scotland's rural resource will be returned to later but first let us further the 
idea that rural Scotland 'matters' (Scottish Office, 2015). Influence, equity and ideas of unity and difference underpin much of the recent policy rhetoric of rural Scotland. Implicitly and explicitly cultural and social capital have positioned at the heart of what is Scotland and the cultural referencing of rurality - rural space and practice as mediating what is 'Scotland' and its success - is crucial to note.

So, secondly, how capital is organised and mediated via ownership, capacities and competencies for leadership and change is differentiated by a number of factors, not least the extent to which such capital can be said to be aligned to either individual or holistic ('social') concerns (Horlings, 2012), and indeed the interplay between public and private sectors locally, and the role played by sector brokers such as education and media, not least in terms of narratives and initiatives underpinning commitment to sustainable development goals, is worthy of further focus. ${ }^{\text {iv }}$ Enterprise and entrepreneurship in Scotland is a complex yet complementary interplay and exchange between both private and public (community/social/national) stakeholders and, arguably, again perhaps nowhere more so as within a rural domain where the connectivity and situated nature of ruralness and remoteness powerfully inform the nature of all enterprise within such places and its capacity for wider growth and stimulus. In this regard Scotland offers a timely case study for a broader international comparison of small island enterprise and economics (c.f. Haskins, 2012; Pato and Teixeira, 2016). The emphasis on the resources of the remote periphery and the very 'islandness' of the place has moved far beyond a simple touristic 'other' matrix of potential enterprise and development focus and rather remote island spaces offer significant test beds for a range of innovative responses to locational challenge but also increasingly position products as singular, desirable and affirming to national and international consumers (Brennan et al., 2016). Food, drink, art, craft are all existing examples of products that are already demonstrating considerable capacity to reach beyond the island's locational 
geography. In Scotland an interesting opportunity is emerging to map more thoroughly the differential of ownership and scale in respect of these enterprises as some such as whisky or salmon may well be part of large-scale global conglomerate enterprises whilst other products such as bakery goods, jewellery or candles may be more typically built around either household family firms or SME operations. Furthermore, despite global market success for Scottish products generally (for example, see Scotland Food and Drink, 2014), there is an ambition and a strategic focus such as Scotland's Smart Exporter programme to develop this more fully. In response to previous decades of policy experience, Scotland's enterprise bodies at national and regional levels - established earlier as models for RDAs globally (Bellini et al., 2012) - undertook to support a strongly co-ordinated approach to marketing and promotion as well as facilitating shared knowledge on production and distribution, clean technologies and digital infrastructures and this suggests a good practice approach to island economic sustainability more generally (Boto and Biasca, 2012; DC Research, 2014; Haskins, 2012).

Rural areas have become increasingly recognised as key agents of both enterprise and social success for progressive Scottish governments: "Scotland and the communities that live and work there are a vital part of Scotland's heritage, identity and economy. Our rural communities are home to nearly one-fifth of our population and our rural regions contributed over $£ 32$ billion to the Scottish economy in 2011 , accounting for approximately $30 \%$ of total on-shore output." (Lochhead, 2014) Some ten years prior to the current SNP government's position we might see the seeds of a concerted re-focussing on the needs and opportunities of rural Scotland taking shape. In 2005, for example, the then Scottish Labour Government in Scotland's parliament at Holyrood stated the long term planning objective for rural and coastal Scotland was that: 
'Rural Scotland needs to become more confident and forward looking both accepting change and benefiting from it, providing for people who want to continue to live and work there and welcoming newcomers. Traditional ways of living will remain but new ones should function alongside. [...] The clear goal will be to maintain the viability of existing communities and bring new life to many places which have seen years of decline.'

Scottish Government (2005)

Prosperity, a new vigour, and a sense of inclusion coupled with a harnessing of the old with the new has shaped Scotland's rural development and socio-economic policy discourse over the last twenty years. The 'arresting of rural decline', a leitmotif of modern Scotland's historical failure within a UK governance context to prevent or indeed concern itself with rural deprivation, de-population and cultural crisis, operates now as a necessary mantra for Scottish and Westminster governments today. Islands and remote rural spaces articulate with ideas of nation, and of things held as both culturally and environmentally 'good'. Arresting decline is not just a challenge for rural Scotland (Arnason et al, 2009), however. Worlwide, and including regions such as the Arctic (c.f. Dana, 2007; Fugmann, 2012) and Pacific (Royle and Tsai, 2008; Armstrong and Read, 2003; Baldacchino, 2010), appraisals of the remote, the rural and the periphery have registered and are being debated more fully. Globally, despite considerable variation in size and context, small island states experience vulnerability (Boto and Biasca, 2012; Briguglio, 1995). There is an emerging focus on the capacities and competencies of rural spaces and populations to effect transformative change and sustainable practice (Sotarauta et al, 2012), albeit within increasingly sensitised governance agenda and fuelled by an increasingly participatory mediatized world. In Scotland this focus is now well developed and nuanced from previous historical experience: 
'The diversity and distinctiveness of many places needs to be recognised and policies tailored and applied accordingly. This means appropriate development in the right places. It also means that planning has to embrace innovation and entrepreneurship whilst protecting what is valuable through good stewardship'

\section{Scottish Government (2005)}

Today in 2015, remote and rural Scotland has effected a co-ordinated voice informing political and socio-economic agenda within Scotland itself, and offering case studies of success for Europe and elsewhere. Yet Scotland also has an acute awareness of the shifting trends of global competitiveness. Consequently, Scottish economic sectors are seeking to assert themselves more fully on a global stage. Key agencies such as Scottish Enterprise, Highlands and Islands Enterprise, Scottish Development International, Scottish Council for Development and Industry but so too Higher Education partners actively communicate the opportunities to meet shifting global trends, and so recognise and implement the essentials of triple helix economic development: shared knowledge and research. These trends embrace innovation based on specialised advancing of highly skilled and innovative workforces, and complement new active creators and increasingly mobile consumers in developed and emerging economies alike, who are getting to 'know' places and products. This offers Scotland opportunities both physically through business and leisure travel but also via digital connectivity and an increasingly ubiquitous digital footprint of product narrative and experience from whisky to sea-salt, film production to wildlife tourism.

Europe's continued concern to align peripheries with more central regional practice whilst retaining cultural and indicative distinctiveness offers an ongoing sense of greater appreciation of what lies at the 'edge' and the nature of agency, enterprise and change therein. Leadership, for example, and its capacity to be variously enacted within a rural space has been examined (Horlings, 2012), and indeed the gendered nature of rural enterprise and 
entrepreneurship is also well developed within a European context (and offers comparison elsewhere).

\section{Cultural value - peripherality 'meaning': discursive narratives of islandness}

There are enterprises on islands and remote areas serving local and regional markets which have a comparative advantage due to their very isolation and ability to compete where there are no appreciable economies of scale. Others are able to utilise competitive advantages of local natural resources such as, in today's world, renewable energies or access to oil and gas fields (as with Shetland) or fishing (Callaghan et al, 2012). Beyond these, there are niche markets for island firms in areas where monopolistic competition is possible. In the Scottish case, examples can be readily identified in cultural and food and drink sectors, such as microbreweries on Arran, Unst and Skye (Danson et al., 2015), and the value-added quality production of fish products in the Hebrides, for example (Burnett and Danson, 2004), each offering a taste of the islands as a key ingredient of their USP (unique selling point). Rising disposable incomes and the expansion of arts, cultural and other creative industries have been worldwide phenomena, and these have especially impacted in rural communities, while also offering local people the opportunity to map their lifestyle ambitions to particular working ideals (Luckman, 2012). Harling Stalker and Burnett (2015) have argued that islands are significantly noted for their creative and cultural resource potential but also increasingly are defining cultural work practice through their islandness characteristics of peripherality, distance and the situated nature of otherness.

In developed economies, islands and similar places often attract workers and entrepreneurs who work directly with cultural resources as language, the arts, food, heritage - both historical (cultural) and environmental (natural), with migrants engaging with cultural work strongly attracted or 'pulled' to remote rural spaces. So, as we have suggested elsewhere: 'Artists, craftworkers, food and drink, heritage, literary or media related professionals are 
often drawn to remote and peripheral spaces in order to capitalize on key raw materials, or inherent cultural experiences that sparsely populated, environmentally rich and culturally distinct regions offer' (Danson and Burnett, 2014). Generally cultural and creative workers (often self-employed) and entrepreneurs, suffer precarious income security, isolation, and often sporadic or necessarily mobile and fluid employment patterns (Gill and Pratt, 2008), and these aspects all tend to be enhanced further in remote rural and island settings. The tensions and perceptions that in-migration can generate, as incomers may not always be welcome in fragile isolated and remote communities. These are complex matters and relationships and remote places are usually subject to long-established net out-migration as people leave for the prospects of better lives elsewhere yet both migrants out and in-migrants display a range of motivations and experiences. Remote communities -island, coastal, or otherwise - are rarely simply defined by people's indigeneity and location histories (Burnett, 1998). The modern picture across many environments and contexts is further defined in terms of ageing and declining populations, with the young having to leave for better opportunities, unable to return to apply their skills and expertise due to the underdeveloped local labour market (Hecla, 2008). These patterns of demographic change, out- and in-migration inform the nuanced nature of island enterprise opportunities and realities (c.f. Royle and Tsai, 2008, on Ireland's offshore islands and comparison with Vietnam; Jentsch and Simard, 2000, for a survey of international comparisons; see endnote 1 for cases from Vietnam, Europe, North America, Oceania). What that brief assessment suggests is that many in-migrants to remote rural and island areas - whether moving to establish a business, to become self-employed or to take up employment - are typically following the rural lifestyle entrepreneur model from the research from across the developed world (Galloway and Mochrie, 2006; Hindle, 2007; Johnson and Rasker, 1995). Indeed, such movers are considered to be motivated less by growth ambitions than the average entrepreneur (Deakins et al, 2003; Galloway and Levie, 
2001; Galloway and Mochrie, 2006). However, some high-growth entrepreneurs can be identified in island settings but the dominant rhetoric is small, niche, perhaps crafted, and local. As explained above, these characteristics may reflect the limited size of the local market but 'may also be linked to the nature of island based enterprise more broadly where priority is given to meaningful quality of life factors (sustainability, low impact presence, work-life balance) rather than more singular profit and expansion motifs' (Danson and Burnett, 2014). Others (Deakins et al, 2003) have issued warnings for rural communities of a dependency on lifestyle businesses which may lack the skills, experience and ambition necessary for growth, and Deakins and Freel (2009) have seen the lack of entrepreneurship as compounding this threat to the local economy.

As we have argued elsewhere, regardless of the development status of their host nation state, a number of sectors are disproportionately active in realising the advantages they can accrue from their islandness (Danson and Burnett, 2014). These include the cultural and creative music, film, visual art, literature and craft activities but also museums, language and historical enterprise. Beyond these, we noted that other sectors are reasonably advanced in their 'islandness' positioning: especially food and drink, where there are many wellestablished small businesses that have capitalised on the referencing of locality and the uniqueness of places (Johannisson, 2009). Critically, many of these new enterprises are located in evolving niche markets based in global tendencies to reaffirm the value of 'local' as particular, physically rooted and/or culturally distinct. Adding value has been embraced by rural enterprise broadly in food terms but islands too have perhaps even more specifically harnessed the singularity of their experiences and geographic situation to define USP and appeal to market (Burnett and Danson, 2004). Our more recent work has begun to expose the significance of networks and contacts with the mainland, with the core for entrepreneurs and enterprises in remote rural and island environments. Businesses which appear to have limited 
links with the rest of the economy and world, in reality rely on links external to their home location for education and training, with networks and linkages to build on their immediate reservoirs of social capital. Capturing and applying the benefits of such knowledge and relationship stocks and flows seem to be becoming more intensive and important as ITC improves and globalises the economy, while world travellers and consumers drive into new markets based on higher incomes and expenditure on luxury and non-essential consumption and informed by an increasingly sophisticated set of narratives around what presents as a 'good' island resource.

\section{Conclusions}

Faced with the opportunities and challenges of a globalising economy, remote and island economies, entrepreneurs and enterprises in developing and developed countries have been pursuing modernity and development based on their local distinctive cultures, realising the values of their inherent assets in an 'experiential economy' (Lorentzen, and van Heur, 2011). Communities have moved to valorise their cultural and natural heritage, creating enterprises, incomes and jobs from the exploitation of the essential characteristics of the area, consistent with the arguments of Throsby (2001) on the gains from mutually-supporting economic and cultural developments (Leadbeater and Oakley, 1999). Using examples drawn from a number of development contexts, it has been suggested that strategic responses and individual and community reactions to regional challenges have been built up over time to generate confidence and resilience locally, each a major catalyst in supporting enterprise and entrepreneurship. Scotland typically has demonstrated a rediscovery and effectively (re)appropriation of its own cultural and heritage assets from within. This includes a maturing of debate and an embracing of islandness as a resource in and of itself yet one that can be variously defined and articulated for entrepreneurial gain. How might this be experienced elsewhere, and in what policy context? 
These local developments can be seen worldwide where remote rural and island communities in, for example, Vietnamv, Croatia (Vidučić, 2007), the Arctic ${ }^{\mathrm{vi}}$ (Dana, 2007; Fugman, 2012), Abu Dhabi (Davidson, 2009; Sharpley, 2002), confirming this adoption of an enterprisebased regeneration and move to modernity is not confined to the core of the developed world, These developments from across developed, emerging and transitional environments, have been informed by theories and interventions of learning regions (Cooke and Morgan, 1998) and partnership working on how to implement such strategies. Critically, many of the lessons and examples have been drawn from similar areas elsewhere, rather than trickling down and out from core and central regions (Danson and de Souza, 2012).

As Throsby (2015) notes for the Pacific island states, the championing of intangible cultural heritage offers a potential growth solution for small island states but the obstacles to building capacity in the creative and cultural industries including distance from markets, limited digital technology, and poorly articulated market synergies require active development focus, at both local and pan-regional level where co-operation and shared knowledge is key. The capacity for narratives and discourses of policy and governance to 'fix' certain enterprise expectations and norms remain, prompting a suggestion for further research into the deeper interplay between various sectors informed by both public and private objectives and a need for robust critique of the pervading discourse that 'all' small remote island enterprise is 'good' enterprise. It also identifies the need for policies and strategies to be proofed for locational differences and for further research to be undertaken to understand the opportunities offered by rural islands and communities by the sea in a world economy where place perhaps rather than space is increasingly valued; and remoteness is not a wholly negative consequence of modernity for today's remote island entrepreneurs.

\section{Bibliography}


Altman, J. (2003) 'Economic development and participation for remote indigenous communities: best practice, evident barriers, and innovative solutions in the hybrid economy' Presentation to Ministerial Council for Aboriginal and Torres Strait Islander Affairs (MCATSIA), Sydney, 28 November, Available online: http://caepr.anu.edu.au/sites/default/files/Publications/topical/altman_mcatsia.pdf.

Armstrong, H., Ballas, D. and Staines, A. (2006) 'A comparative analysis of the economic performance of Greek and British small islands', Available online: http://www.shef.ac.uk/polopoly_fs/1.20701!/file/greekbritishislands.pdf.

Armstrong, H. and Read, R. (2003) 'mall states, islands and small states that are also islands. Studies in Regional Science 33, 1-24.

Arnason, A., Shucksmith, M. and Vergunst, J. (2009) (eds.) Comparing Rural Development: Continuity and Change in the Countryside of Western Europe, Ashgate, Aldershot.

Atterton, J. (2007) 'The 'strength of weak ties': social networking by business owners in the Highlands and Islands of Scotland' Sociologia Ruralis 47, 228-245

Atterton, J., Newbery, R., Bosworth, G. and Affleck, A. (2011) 'Rural enterprise and neoendogenous development' In: Alsos, G., Carter, S., Ljunggren, E. and Welter, F. (eds.) The Handbook of Research on Entrepreneurship in Agriculture and Rural Development Edward Elgar, London.

Baldacchino, G. (2005) 'Island entrepreneurs: insights from exceptionally successful knowledge-driven SMEs from 5 European Island Territories' Journal of Enterprising Culture 13 (2) $145-170$

Baldacchino, G. (2006) 'Islands, island studies, island studies journal' Island Studies Journal 1 (1) 3-18 
Baldacchino, G. (2010) 'Island brands and 'the Island' as a brand: insights from immigrant entrepreneurs on Prince Edward Island' International Journal of Entrepreneurship and Small Business 9 (4) 378-393

Baldacchino, G. (2012) 'The Lure of the island: A spatial analysis of power relations' Journal of Marine and Island Cultures 1 (2) 55-62

Baldacchino, G., and Fairbairn, T.I.J. (2006) (eds.) 'Entrepreneurship and small business development from small islands' Special issue, Journal of Small Business and Entrepreneurship, 19 (4) 331-430

Baum, T. (1996) 'The fascination of islands: The tourist perspective' In: Lockhart, D. and Drakakis-Smith, D. (eds.) Island Tourism: Problems and Perspectives Pinter, London 21-35.

Bellini, N., Danson, M., and Halkier, M. (2012) (eds.) Regional Development Agencies: the Next Generation? Routledge, London.

Boto, I., and Biasca, R. (2012) 'Small island economies: from vulnerabilities to opportunities - a reader overview of development issues in Small Island Developing States (SIDS)' CTA Briefing no. 27 Brussels $4^{\text {th }}$ April, 2012, Available online at: http://brusselsbriefings.net

Brennan, S., Danson, M., and O'Rourke, B. (2016) 'Selling a language to save it? The business-oriented promotion of Gaelic and Irish' in McLeod, W. Canan and Cultar (Language and Culture): Rannsachadh na Gaidhlig 8 205-221, Dunedin, Edinburgh.

Burnett, J. A. (2011) The Making of the Modern Scottish Highlands, 1939-1965: Withstanding the 'Colossus of Advancing Materialism' Four Courts, Dublin.

Burnett, K.A. (1998) 'Local heroics: reflecting on incomers and local rural development discourses in Scotland' Sociologia Ruralis 38 (2) 204-224 
Burnett, K.A. and Danson, M. (2004) 'Adding or subtracting value?' Constructions of rurality and Scottish quality food promotion' International Journal of Entrepreneurial Behaviour \& Research 10 (6) $384-403$

Briguglio, L. (1995) 'Small Island States and their Economic Vulnerabilities', World Development 23 (9) 1615-1632

Bryden, J. and Geisler, C. (2007) 'Community-based land reform: lessons from Scotland' Land Use Policy 24, 24-34

Callaghan, G., Danson, M. and Whittam, G. (2012) 'Economic and enterprise development in community buy-outs', in M. Danson and P. de Souza (eds.) Regional Development in Northern Europe: Peripherality, Marginality and Border Issues Routledge, Abingdon

Cameron, G., and Danson, M. (1999) 'The European partnership model and the changing role of regional development agencies. A regional development and organisation perspective', in M. Danson, H. Halkier and G. Cameron (eds.) Governance, Institutional Change and Development Ashgate, London.

Carothers, C. (2010) 'Tragedy of commodification: displacements in Alutiiq fishing communities in the Gulf of Alaska' MAST 9 (2) 95-120

Cooke, P., and Morgan K. (1998) The Associational Economy: Firms, Regions, and Innovation, Oxford University Press, Oxford.

Clifford, J. (2001) 'Indigenous Articulations' The Contemporary Pacific 13 (2) 468-490

Curran, J. and Storey, D. (1993) Small Firms in Urban and Rural Locations Routledge, London. 
Dana, L-P. (2007) 'A comparison of indigenous and non-indigenous enterprise in the Canadian sub-Arctic' International Journal of Business Performance Management 9 (3) 278286

Danson, M., and Burnett, K. (2014) 'Enterprise and entrepreneurship on islands' in C. Henry and G. McElwee (eds.) Exploring Rural Enterprise: New Perspectives on Research, Policy and Practice Emerald, Bingley 151-174

Danson, M. and de Souza, P. (2012) 'Periphery and marginality: definitions, theories, methods and practice' in M. Danson and P. de Souza (eds.) Regional Development in Northern Europe: Peripherality, Marginality and Border Issues Routledge, Abingdon 1-15

Danson, M., Galloway, L., Cabras, I. and Beatty, C. (2015) 'Microbrewing and entrepreneurship: the origins, development and integration of real ale breweries in Britain' International Journal of Entrepreneurship and Innovation Management 16 (2), 135-144

Danson, M., Helinska-Hughes, E. and Hughes, M. (2005) 'RDAs and benchmarking: learning from good practice when the model has broken' Public Policy and Administration 20 (3) 4-22

Danson, M., and Lloyd, G. (2012) 'Beyond devolution: roads to coherent autonomies?' Environment and Planning C 30 (1) 78-94

Davidson, C. (2009) 'Abu Dhabi's new economy: oil, investment and domestic development' Middle East Policy 16 (2)59-79

DC Research (2014) Ar Stòras Gàidhlig: Economic and Social Value of Gaelic as an Asset (Final Report May 2014) Highlands and Islands Enterprise, Inverness.

Deakins, D., Galloway, L. and Mochrie, R. (2003) 'The use and effect of ICT on Scotland's rural business community’ Research report for Scottish Economists' Network. 
Deakins, D. and Freel, M. (2009) Entrepreneurship and Small Firms $5^{\text {th }}$ Edition McGrawHill, Maidenhead.

DeLoughrey, E. (2007) Routes and Roots: Navigating Caribbean and Pacific Island Literatures University of Hawaii Press, Honolulu, HI.

Dubois, A. (2013) Managing Distance: Small Firm Networks at the Geographic Margins. (Doctoral dissertation) Department of Human Geography, Stockholm University, Stockholm. Edmond, R. and Smith, V. (2003) (eds.) Island in History and Representation Routledge, London.

Efimova, E.G. and Kuznetsova, N.P. (2012) 'Economic development of ultra small peripheral West European regions (Case of Åland and Faroe)' Ekonomika 91 (3) 7-26

Etzkowitz, H. and Ranga, M. (2010) 'A triple helix system for knowledge-based regional development: from "spheres" to "spaces", paper to The Triple Helix VIII International Conference on University, Industry and Government Linkages, Madrid, Spain.

Fugmann, G. (2012) 'Developing a remote region: Tourism as a tool for creating economic diversity in Nunatsiavut' Études/Inuit/Studies 36 (2) 13-33

Galloway, L. and Levie, J. (2001) Global Entrepreneurship Monitor: Scotland University of Strathclyde, Glasgow.

Galloway, L. and Mochrie, R. (2006) 'Entrepreneurial motivation, orientation and realization in rural economies: A study of rural Scotland' The International Journal of Entrepreneurship and Innovation 7 (3) 173-183

Gill, R. and Pratt, A. (2008) 'In the social factory?: Immaterial labour, precariousness and cultural work' Theory, culture, and society 25 (7-8) 1-30 
Graham, L. and Penny, H. (2014) (eds.) Performing Indigeneity: Global Histories and Contemporary Experiences University of Nebraska Press, Lincoln.

Haskins, J. (2012) 'Policy Brief no. 8 - Building resilience in small island economies: From vulnerabilities to opportunities', CTA publications, Available online: http://publications.cta.int/en/publications/publication/PB008E/

Harling Stalker, L., and Phyne, J. (2014) 'The social impact of out-migration: A case study from rural and small town Nova Scotia, Canada' The Journal of Rural and Community Development 9 (3) 203-226

Harling Stalker, L.L. and Burnett K.A. (2016) 'Good Work?: Scottish cultural workers' narratives about living and working on islands' Island Studies Journal 11 (1) 193-208 Harvey, D. (2006) Towards a Theory of Uneven Geographical Development Verso, London and New York.

Hay, P. (2006) ‘A phenomenology of islands’ Island Studies Journal 1 (1) 19-42

Hecla Consulting (2008) 'Measuring the Gaelic labour market: Current and future potential' Hecla Consulting, Inverness.

Heddle, D. (2010) 'The Norse element in the Orkney dialect' in Millar, R. (ed.) Northern Lights, Northern Words. Selected Papers from the FRLSU Conference Kirkwall 2009. Aberdeen: Forum for Research on the Languages of Scotland and Ireland, 48-57.

Henry, C. and McElwee, G. (eds.) (2014) Exploring Rural Enterprise: New Perspectives on Research, Policy and Practice Emerald, Bingley

Hennessy, E. and McCleary, A. (2011) 'Nature's Eden? The production and effects of 'pristine' nature in the Galápagos Islands' Island Studies Journal 6 (2) 131-156

HIE (Highlands and Islands Enterprise) (2011) 'Tourism businesses urged to capitalise on growth in Scotland's sailing market' Highlands and Islands Enterprise, Accessed online: 
http://www.hie.co.uk/about-hie/news-and-media/archive/tourism-businesses-urged-to-set-

their-ship-on-course-to-capitalise-on-growth-in-scotland-s-sailing-

market.html\#sthash.zZSSbI6L.dpbs

Hindle, R. (2007) 'Innovation in small rural businesses' in S. Mahroum, J. Atterton, N. Ward, A.M. Williams, R. Naylor, R. Hindle and F. Rowe (eds.) Rural Innovation, Exploration 01: December, NESTA.

Horlings, I. (2012) 'The interplay between social capital, leadership and policy arrangements in European rural regions' in M. Sotarauta and I. Horlings, and J. Liddle (eds.) Leadership and Change in Sustainable Regional Development Routledge, Taylor Francis, London and New York.

Hunter, J. (2010) The Making of the Crofting Community, Birlinn, Edinburgh.

Jentsch, B., and Simard, M. (2009) (eds.) International Migration and Rural Areas: CrossNational Comparative Perspectives Ashgate, London

Johannisson, B. (2009) 'Networking and entrepreneurship in place' pp. 137-162 in M.A.

Galindo, Guzman, J. and D. Ribeiro (eds.) Entrepreneurship and Business: A Regional Perspective, Berlin, Springer.

Johnson, J. and Rasker, R. (1995) 'The Role of Economic and Quality of Life Values in Rural Business Location' Journal of Rural Studies 11(4) 405-416.

Kelman, I. (2007) 'Sustainable livelihoods from natural heritage on islands' Island Studies Journal 2 (1) 101-114

Leadbeater, C., and Oakley, K. (1999) The Independents: Britain's new cultural entrepreneurs Demos, London. 
Lochhead, R. (2014) 'Forward', in Scottish Government (2014) Scotland's Future: Connecting Rural Scotland, Accessed online: www.scotland.gov.uk. $7^{\text {th }}$ 0ctober 2015.

Lorentzen, A., and van Heur, B. (2011) Cultural Political Economy of Small Cities Routledge, Abingdon.

Lowe, P., Ray, C., Ward, N., Wood, N. \& Woodward, R. (1998) 'Research report: participation in rural development: A review of European experience' Centre for Rural Economy, Newcastle. Available online: http://www.ncl.ac.uk/cre/publish/pdfs/rr98.1a.pdf Luckman, S. (2012) Locating Cultural Work: The Politics and Poetics of Rural, Regional and Remote Creativity Palgrave Macmillan, Basingstoke.

McCall, G. (1994) 'Nissology: a proposal for consideration' Journal of the Pacific Society 17(2-3) $1-14$

McIntosh, S., and Renard, Y. (2009) 'Placing the commons at the heart of community development: Three case studies of community enterprise in Caribbean islands' International of the Commons 4 (1) 160-182.

Mulholland, N. (2008) 'The cultural economy: Old lamps for New Labour?' Renewal: $a$ journal of social democracy 16 (2) 35-44

Nicolson, A. (2002) Sea Room: An Island Life in the Hebrides London, Harper Collins.

North, D. and Smallbone, D. (2006) 'Developing entrepreneurship and enterprise in Europe's peripheral rural areas: some issues facing policy-makers' European Planning Studies 14 (1) $41-60$

OECD (2005) Culture and Local Development OECD Publishing, Paris.

O'Gorman, C. and Evers, N. (2011) 'Network intermediaries in the internationalisation of new firms in peripheral regions' International Marketing Review 28 (4) 340-364 
Pato, M. L. and Teixeira, A.A.C. (2016) Twenty years of rural entrepreneurship: a bibliometric survey. Sociologia Ruralis 56 (1) 3-28

Rowe, F. (2011) 'Rural policy in Scotland and England: A comparative perspective'. Rural Policy Centre Research Report Scottish Agricultural College, Scotland.

Royle, S. (2008) 'From marginality to resurgence: the case of the Irish islands' Shima: The International Journal of Research into Island Cultures 2 (2) 42-5

Royle, S. and Tsai, H-M. (2008) 'Cultural heritage and development strategies of the offshore islands of Ireland and Taiwan' Insula, International Journal of Island Affairs 17 (1) 47-56

Scottish Executive (2005) Choosing our future: Scotland's sustainable development stratey, Scottish Executive, Edinburgh

Scottish Government (2016) Global Scotland - Scotland's Trade and Investment Strategy 2016-2021 March 2016, Scottish Government: Edinburgh Available online: http://www.gov.scot/Publications/2016/03/7779/326364

Shortall, S. and Alston, M. (2016) To Rural Proof or Not to Rural Proof: A Comparative Analysis. Politics \& Policy, 44: 35-55

Skerratt, S., Atterton, J., Brodie, E., Carson, D., Heggie, R., McCracken, D., Thomson, S. and Woolvin, M. (2014) Rural Scotland in Focus 2014, Edinburgh: Rural Policy Centre, SRUC, Scotland's Rural College.

Scotland Food \& Drink (2014) 'Scotland: A land of food and drink. An export plan for Scotland's food and drink industry' Edinburgh.

Scottish Government (2005) Scottish Planning Policy 15: Planning for Rural Development Accessed online: http://www.gov.scot/Publications/2005/02/20624/51512. 
Scottish Office (2015) Comhairle nan Eilean Siar, Orkney Islands Council and Shetland Islands Council UK Government and the Three Scottish Islands Councils: A Framework for the Islands Available online: https://www.gov.uk/government/news/10-point-plan-forscottish-islands Accessed 18 March 2015

Sharpley, R. (2002) 'The challenges of economic diversification through tourism: the case of Abu Dhabi’ International Journal Tourism Research 4 221-235

Shucksmith M, Chapman P, and Clark G (1996) Rural Scotland Today: the best of both worlds? Avebury: Aldershot

Smallbone, D. and Welter, F. (2006) 'Conceptualising entrepreneurship in a transition context', Int. J. Entrepreneurship and Small Business, 3(2) 190-206

Smallbone, D., Welter, F. and Ateljevic, J. (2014) 'Entrepreneurship in emerging market economies: contemporary issues and perspectives' International Small Business Journal 32 (2) $113-116$

Smith, N. (1990) Uneven Development: Nature, Capital and the Production of Space, $2^{\text {nd }}$ edn. Blackwell, Oxford.

Soja, E. W. (1985) 'Regions in context: spatiality, periodicity, and the historical geography of the regional question' Environment and Planning D 3 175-190

Sotarauta, M., Horlings, I. and Liddle, J. (2012) (eds.) Leadership and Change in Sustainable Regional Development Routledge Taylor Francis, London and New York.

Throsby, D. (2001) Economics and Culture Cambridge University Press, Cambridge.

Throsby, D. (2015) 'Development strategies for Pacific Island economies: Is there a role for the cultural industries?' Asia \& the Pacific Policy Studies 2 (2) 370-382 
Tisdell, C. (2006) 'Economic prospects for Small Island Economies, particularly in the South Pacific, in a globalising world' School of Economics, The University of Queensland. Accessed online: http://ageconsearch.umn.edu/handle/90547

UNCTAD (2013) Creative Economy Special Report 2013 Widening Local Development Pathways Available online: http://www.unesco.org/new/en/culture/themes/creativity/creative-economy-report-2013special-edition/

Vidučić, V. (2007) 'Sustainable development of island tourism in Republic of Croatia, Our Sea' International Journal of Maritime Science and Technology 54 (1-2) 42-48

Whittam, G. and Danson, M. (2001) 'Power and the spirit of clustering' European Planning Studies 9 (8) 949-963

\footnotetext{
' Leading the way in tackling inequality, The Scottish Government, 19/07/2015Access online at : http://news.scotland.gov.uk/News/Leading-the-way-in-tackling-inequality-1b49.aspx; See also : NIDOS: Network of International Development Organisations in Scotland Available online at www.nidos.org.uk

ii The two-year independence referendum campaign generated much reflection on the state of the country and what sort of future people envisaged. Since the 'No' vote (September, 2014) and the not unrelated opening of the debate on the UK's role and membership of the European Union, the shifting political economy landscapes across the whole UK have led to reappraisals of Scottish and other nations' identities, economies and sustainability agenda with obvious implications for the issues introduced here. It seems no coincidence that these are leading in turn to a recognition and redefining of the cultural and heritage identities of the country as especially interesting realms for enterprise.

iii Poverty, social exclusion and environmental vulnerabilities are all noted as key current drivers of sustainability agenda for Scotland's remote rural islands. Enterprise is key to both responsive planning as well as brining challenges to previous history and practice. See for
} 
example http://www.hie.co.uk/regional-information/economic-reports-and-

research/archive/a-minimum-income-standard-for-remote-rural-scotland.html.

iv See for example the focus within Scotland's education sector prioritising sustainability within business and enterprise development agenda, including developing centres for research excellence. Access online at: http://www.gov.scot/Topics/Environment/SustainableDevelopment

v As evidenced by the even: "The Safeguarding and Promoting of Sea and Island Culture of Vietnam.

International Conference", Nha Trang City, Vietnam. 5 January 2015. Organized by Ministry of

Culture, Sports and Tourism, Vietnam National Institute of Culture and Arts Studies

${ }^{\mathrm{vi}}$ where the transnational University of the Arctic has begun to offer teaching, research and

knowledge exchange opportunities in the region 